\title{
The Early-Middle Pleistocene Transition: characterization and proposed guide for the defining boundary
}

\author{
1 Department of Earth Sciences, Brock University, St Catharines, Ontario, L2S 3A1, Canada. Email: mjhead@brocku.ca \\ 2 Research School of Earth Sciences, The Australian National University, Canberra, ACT, 0200, Australia. \\ 3 Cambridge Quaternary, Department of Geography, University of Cambridge, Downing Place, Cambridge, CB2 3EN, United Kingdom.
}

\begin{abstract}
The mid-Pleistocene transition (MPT, c. 1.2 to $0.5 \mathrm{Ma}$ ) records fundamental changes in Earth's climate state, where low-amplitude 41-kyr obliquity-dominated cycles gave way progressively to the high-amplitude, quasiperiodic (c. 100-kyr) fluctuations that characterize the later Pleistocene and Holocene. We use wavelet analysis on the LRO4 $\delta^{18} \mathrm{O}$ benthic foraminiferal stack to confirm low-frequency power as early as 1.25-1.20 Ma, determine the persistence of obliquity-dominated cyclicity through and beyond the MPT, and reveal new levels of complexity in climate evolution. Beginning around 900 kyr, successive major glaciations, most notably in the northern hemisphere, profoundly affected the biota and physical environment. The Matuyama-Brunhes palaeomagnetic Chron boundary (c. $773 \mathrm{ka}$ ) is close in age to a major glacial event, occurs approximately at the middle of the MPT, and is widely identified in marine and terrestrial deposits. It would serve as the best overall guide for the Early-Middle Pleistocene Subseries/Sub-epoch boundary.
\end{abstract}

\section{Introduction}

The mid-Pleistocene transition (MPT, c. 1.2-0.5 Ma) is widely recognized in both marine and continental strata as marking a major global climatic reorganization that profoundly affected ocean and atmospheric circulation, ice sheets and the distribution and evolution of biota, including the ancestors of modern humans (Figure 1). During this transition, low-amplitude 41-ka obliquity-driven climatic cycles of the earlier Pleistocene were progressively overshadowed by quasi-periodic, low frequency (c. $100 \mathrm{kyr}$ ) fluctuations in the later Pleistocene. This low-frequency cyclicity was driven by precessional forcing ( $23 \mathrm{kyr}$ period), with each cycle defined by the fourth or fifth precessional cycle (Maslin and Ridgwell, 2005), and is characterized by a succession of severe glacial episodes particularly in the northern hemisphere.

Orbital forcing parameters do not vary significantly across the MPT, implying that non-linear internal feedbacks in the Earth climate system are responsible for the transition. The pronounced asymmetrical 'saw-tooth' pattern of climate cycles after about 700 ka (Figures 1,2), indicating slow ice buildup and subsequent rapid melting, also reflects nonlinear forcing of the climate system (Maslin and Ridgwell, 2005). Most hypotheses for the origin of the MPT invoke a response to long-term cooling, driven by such possible mechanisms as ice-sheet dynamics (Clark et al., 2006) or a secular decline in atmospheric $\mathrm{CO}_{2}$ (Maslin and Ridgwell, 2005).

To elucidate variations in cyclicity over the past $1500 \mathrm{kyr}$, we briefly present the wavelet analysis of a compilation of marine benthic foraminiferal $\delta^{18} \mathrm{O}$ records known as the LR04 stack (Lisiecki and Raymo, 2005). We then review major climatic events from the marine and terrestrial realms (from Head and Gibbard, 2005 and references therein, unless otherwise stated; Figure 1); and because the MPT has long been used to broadly define the boundary between the Early and Middle Pleistocene, we finally summarize recent progress in assessing candidate GSSPs for a formal definition of the Early-Middle Pleistocene Sub-series/Sub-epoch boundary.

\section{Wavelet analysis}

Wavelet spectra are useful for analyzing localized variations of power within a time series (Torrence and Compo, 1998). The LR04 stack averages $\delta^{18} \mathrm{O}$ records from 57 sites, and produces a global signal relatively free of local effects. Wavelet analysis of this stack was performed using the MATLAB ${ }^{\circledR}$ Wavelet Toolbox ${ }^{\mathrm{TM}}$ (following Torrence and Compo, 1998) with the following parameters: continuous wavelet 1-D; wavelet $=$ Morlet; scale settings: 'step by step mode' $; \min =1 ;$ step $=1 ; \max =64$. The cone of influence (as defined by Torrence and Compo, 1998) $=2^{\wedge}(1 / 2)$ x scale. Our analysis of this stack (Figure 2) shows that:

1) low frequency variability: i) begins at $1.25-1.20 \mathrm{Ma}$ (Marine Isotope Stage [MIS] 38-36) with increased power in the 70-kyr band; ii) gains power in the 85-110-kyr band from c. 1000-900 ka (MIS 29-23), with power in this band intensifying from c. 700-650 ka (MIS 17-16); and iii) is complex and quasi-periodic within the detection limits of this time span.

2) power in the 41-kyr obliquity-dominated band remains constant through the examined interval, and precession-related cyclicity at c. $23 \mathrm{kyr}$ is also present throughout.

Our results broadly compare with those from other time series analyses, such as the moving window Fourier transform used by Clark et al. (2006) on the LR04 stack. However, wavelet analysis methods provide an improvement on the Fourier techniques, especially where there are transient shifts in the periodicities of the responses to forcing patterns. Thus, although Clark et al. (2006) showed that the c. 100-kyr climate cycle emerged at $1.25 \mathrm{Ma}$ and reached full amplitude by $700 \mathrm{ka}$, wavelet analysis reveals a more detailed and complex picture of low frequency variability beginning at 1.25-1.20 Ma and evolving through the interval examined, as detailed above. 


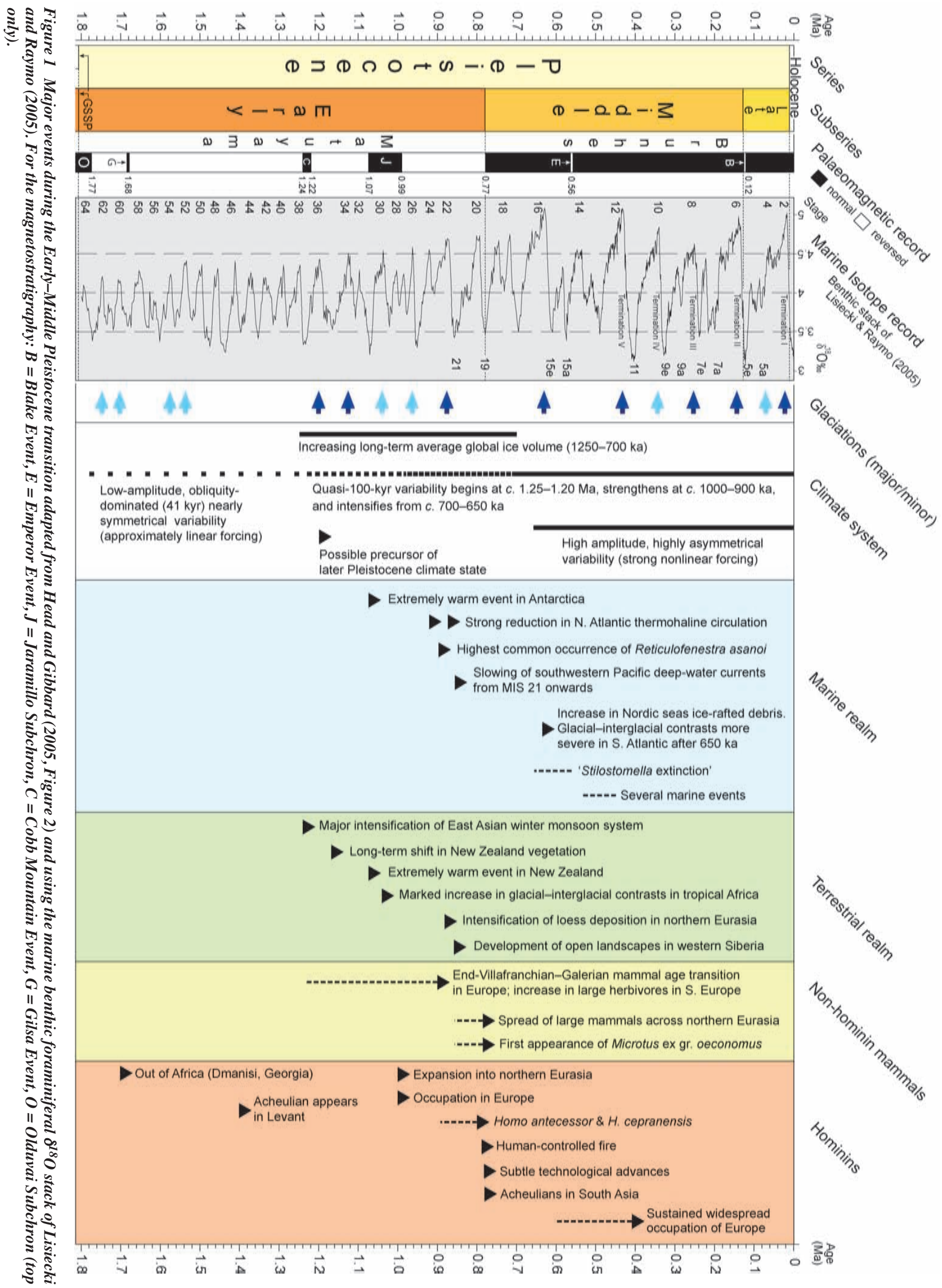




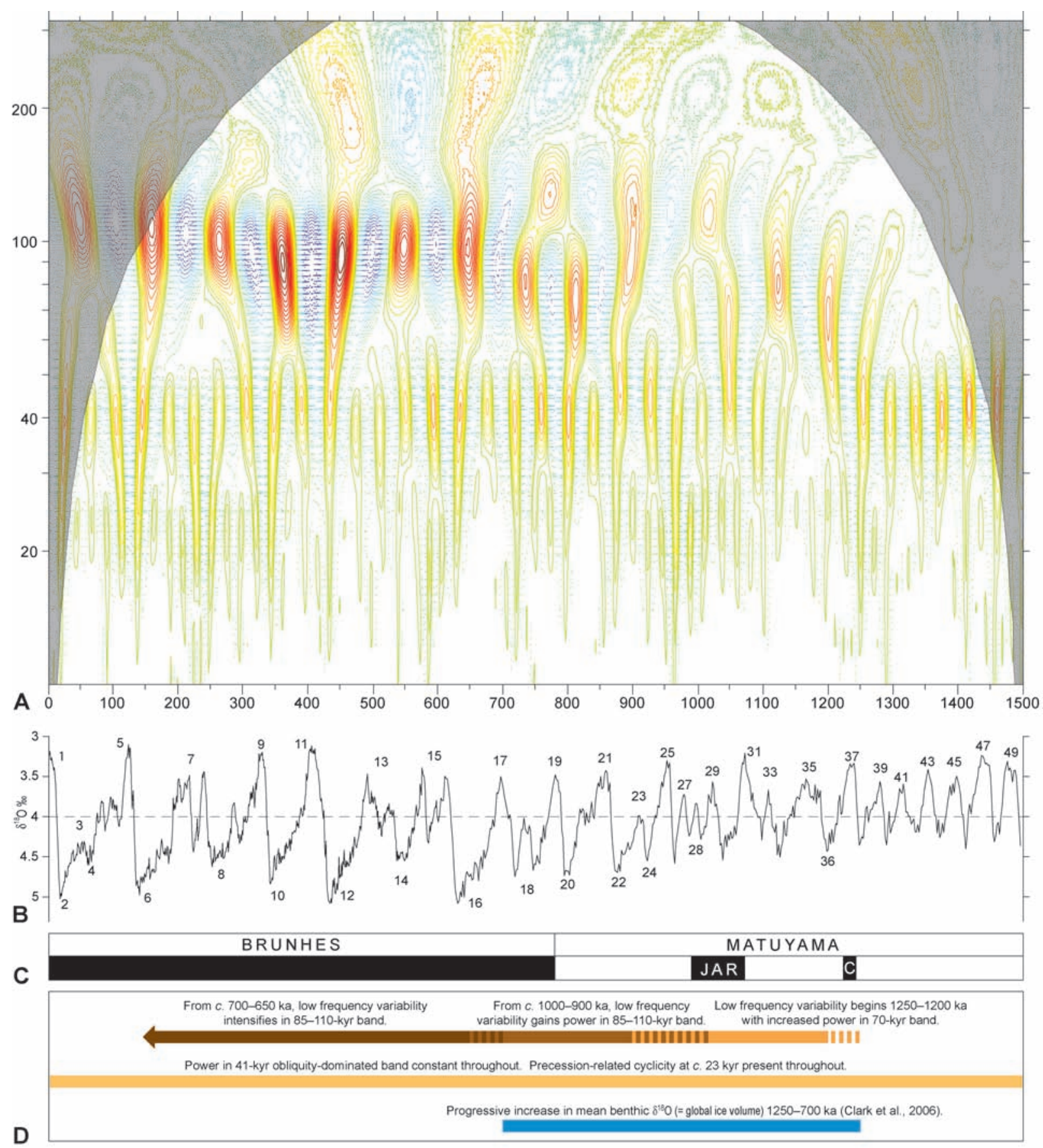

Figure 2 A. Wavelet spectrum of the LR04 stack for the interval 0-1500 ka (see text for details). B. The corresponding LR04 stack of benthic foraminiferal $\delta^{18} \mathrm{O}$ records from 57 globally distributed sites (Lisiecki and Raymo, 2005). C. Magnetostratigraphy showing the position of the Matuyama-Brunhes boundary, which we propose as the primary chronostratigraphic guide for the Early-Middle Pleistocene boundary. JAR = Jaramillo Subchron, C = Cobb Mountain Event. D. Main transitions indicated by the wavelet spectrum of the LR04 stack. The interval of global ice increase (Clark et al., 2006) is also given.

\section{Marine records}

The MPT is characterized by a long-term average global ice-volume increase between 1.25 Ma and $700 \mathrm{ka}$ (Clark et al., 2006). MIS 36 (c. $1.20 \mathrm{Ma}$ ) coincides approximately with the beginning of low-frequency oscillations (Figure 2), supporting suggestions that this was a precursor to the later Pleistocene nonlinear state. However, both marine (Clark et al., 2006) and terrestrial records (Sun et al., 2006, see below) imply a slightly earlier age $(1.25 \mathrm{Ma})$ for the onset of severe climatic conditions. In the southeastern South Atlantic, contrasts in glacial-interglacial ocean circulation strengthened from this time onwards. MIS 24 and 22 (920 and $880 \mathrm{ka}$ ) represent the first major cooling phase of the MPT and are associated with strong reductions in North Atlantic thermohaline circulation. The MIS 23-22 transition (c. $890 \mathrm{ka}$ ) is associated with the highest common occurrence of the nannofossil Reticulofenestra asanoi, an important datum for the MPT in the Mediterranean and North Atlantic. Decreased production of North Atlantic Deep Water (NADW) during the MPT was likely the result of increased northern hemisphere glaciation, with increased ice-rafted debris evident in the Nordic seas from about $650 \mathrm{ka}$. At least 50 species of deep-sea benthic foraminifera are known to have become extinct during the MPT. These data probably reflect slower deep ocean circulation and reduced deepwater ventilation during the MPT. Marine events are depicted on Figure 1. 


\section{Continental records}

Evidence for climate change is more visible, if less complete, on land. The classic loess-paleosol sequences of northern Eurasia and China are among the longest complete continental records of the Quaternary, revealing the alternation of dry and humid conditions on orbital time scales correlated to the marine record. Several key events are recognized from the Chinese Loess Plateau: the interval 1.25-0.52 Ma represents a substantial increase both in the amplitude of the winter monsoon variation and its intensity, and a weakened summer monsoon (Sun et al., 2006). The deserts in northern China are inferred to have expanded significantly at around $1.2 \mathrm{Ma}$ (Ding et al., 2005). After $0.52 \mathrm{Ma}$, the mean and amplitude of both the summer and winter monsoon variation increased greatly (Sun et al., 2006). The appearance of thicker loess horizons in northern Eurasia after about 1.0 Ma marks the onset of more pronounced c. 100-kyr cycles, with loess accumulation becoming particularly intensified during the severely cold conditions associated with MIS 22 (Dodonov, 2005). In the Chinese Loess Plateau, both the upper part of the L9 loess horizon (MIS 22, $0.87 \mathrm{Ma}$ ) and the loess horizon L15 (MIS 38, 1.25 Ma) have especially high peaks in the coarser sediment fraction (Sun et al., 2006), and reflect severe climatic conditions.

Other continental paleoenvironmental records, particularly from lacustrine and fluvial sediments, reveal complex responses through the MPT. For example, a major shift occurs in the pollen record of a site in New Zealand at MIS 35, resulting in a permanent increase in southern beech forests. Tzedakis et al. (2006) showed using a pollen record from Greece that extreme glacial conditions during MIS 22 and 16 were largely responsible for the extirpation of many relict taxa. However, the extinction of themophilous plant taxa was not restricted to the MPT but time-transgressive over much of the Quaternary, with extinctions occurring earlier in northern (colder) parts than in southern parts of the Mediterranean province. Thus, extinctions of plant taxa are not generally suitable for use as high-resolution chronostratigraphic horizons in the Quaternary.

The large and small mammal records show significant regional reorganizations through the MPT, including the first European records of the extant leopard and spotted hyaena. As open landscapes developed, the steppe mammoth first appeared across northern Eurasia at around 850-770 ka. Hominins underwent a complex history of migrations and evolution during the MPT, including early migrations into higher northern latitudes by about $1.0 \mathrm{Ma}$, probably following migrations of large herbivores that would have served as a food and commodity source, and critically leading to increased colonizing capacity. Continental events are depicted on Figure 1.

\section{Middle Pleistocene GSSP}

Fundamental changes in the Earth's climate system, and associated biotic and physical events, occurred progressively during the interval c. 1.2 to $0.5 \mathrm{Ma}$. Consequently, several positions for the Early-Middle Pleistocene boundary have been suggested (see Head and Gibbard, 2005 for discussion), including the MIS 22-21 transition and the originally-proposed boundary between the Calabrian and Ionian marine stages in Italy (perhaps within MIS 25, but see below). However, support has been greatest for the Matuyama-Brunhes boundary (see Head and Gibbard, 2005 for discussion). For example, participants at the Burg Wartenstein Symposium 'Stratigraphy and Patterns of Cultural Change in the Middle Pleistocene', held in Austria in 1973, recommended that 'The beginning of the Middle Pleistocene should be so defined as to either coincide with or be linked to the boundary between the Matuyama Reversed Epoch and the Brunhes Normal Epoch of paleomagnetic chronology' (Butzer and Isaac, 1975, appendix 2). A similar recommendation was made by the International Union for Quaternary Research (INQUA) Working Group on Major Subdivision of the
Pleistocene at the XIIth INQUA Congress in Ottawa in 1987 (Richmond, 1996). There has since been widespread use of the Matuyama-Brunhes boundary (MBB) in defining the Early-Middle Pleistocene boundary (e.g., Bowen, 1988; Berggren et al., 1995; Gradstein et al., 2005). It should be noted that in newly redefining the Italian marine stages, Cita et al. (2006) and Cita (this issue) have now proposed the Matuyama-Brunhes boundary as the guiding criterion for the base of the Ionian Stage. This would result in a satisfactory unification of the Early-Middle Pleistocene boundary with the Calabrian-Ionian Stage boundary in Italy.

At the XIVth INQUA Congress in Berlin in 1995, the search for a suitable boundary stratotype section was focussed on three sections in Japan, New Zealand, and Italy. However, the New Zealand section was discounted because it contained unconformities.

In 2002, a Working Group of the International Commission on Stratigraphy (ICS) Subcommission for Quaternary Stratigraphy was established to review all aspects of the Early-Middle Pleistocene boundary including its position within the MPT and selection of a suitable GSSP. At the 32nd International Geological Congress in Florence in 2004, the Working Group recommended that:

1. The E-M Pleistocene boundary be defined in a marine section at a point 'close to' the Matuyama-Brunhes boundary. The definition of 'close' was agreed to mean within plus or minus one isotope stage of the MBB.

2. The GSSP should be located in a marine section exposed on land, not in a deep sea core.

Three candidate sections are presently being considered by the Working Group:

1. Montalbano Jonico section in Italy (Ciaranfi and D'Alessandro, 2005).

2. Valle di Manche section in Italy (Capraro et al., 2005).

3. Chiba section in Japan (Pickering et al., 1999).

Of the first two, the Montalbano Jonico section is expanded relative to the Valle di Manche section, but weathering has caused difficulties for developing a magnetostratigraphy at Montalbano Jonico (Cita, this issue).

\section{The chronostratigraphic importance of the Matuyama-Brunhes reversal}

Chronostratigraphic markers should ideally be recognized in both marine and continental sequences. Widespread tephra beds are regionally useful, as are Australasian tektites (Pillans, 2003), but the MBB offers truly global potential. It also occurs at around the middle of the MPT as defined by the events summarized above, within the interval of increasing global ice volume, and within the transitional interval (c. 1000-900 to 700-650 ka) identified in our own wavelet analysis of the LR04 stack (Figure 2). Moreover, it is close in age to a major glacial event represented by MIS 22 (Figure 1).

High-resolution marine studies give a duration of 5-7 ka and a mid-point at about $773 \mathrm{ka}$ for the MBB (Channell et al., 2004). The MBB coincides with the middle of MIS 19, although problems of displaced magnetic remanence in northern Eurasian and Chinese loess-palaeosol sequences cause it to occur misleadingly in sediments assigned to MIS 20 (Zhou and Shackleton, 1999; Dodonov, 2005). Nonetheless, the MBB remains a crucial stratigraphic guide both on land and at sea.

In closing, we concur with Butzer and Isaac (1975), Richmond (1996), Pillans (2003), and Head and Gibbard (2005) that the MBB should be the primary chronostratigraphic guide for defining and correlating the Early-Middle Pleistocene boundary. However, we emphasize that the MBB is only one of multiple criteria that will be used for local, global and regional correlation of the boundary. 


\section{Acknowledgements}

We are most grateful to Andy Ridgwell for his detailed review of the manuscript, and to Phil Gibbard for discussions.

\section{References}

Berggren, W.A., Hilgen, F.J., Langereis, C.G., Kent, D.V., Obradovich, J.D., Raffi, I., Raymo, M.E. and Shackleton, N.J., 1995. Late Neogene chronology: New perspectives in high-resolution stratigraphy: Geological Society of America Bulletin, 107,pp. 1272-1287.

Bowen, D.Q., 1988. Quaternary Geology: A Stratigraphic Framework for Multidisciplinary Work: Pergamon Press, Oxford, 237 pp.

Butzer, K.W., and Isaac, G.L. (Editors), 1975. After the Australopithecines. Mouton, The Hague, 911 pp.

Capraro, L., Asioli, A., Backman, J., Bertoldi, R., Channell, J.E.T., Massari, F., and Rio, D., 2005. Climatic patterns revealed by pollen and oxygen isotope records across the Matuyama-Brunhes Boundary in the central Mediterranean (southern Italy). In: M.J. Head and P.L. Gibbard (Editors), Early-Middle Pleistocene transitions: the land-ocean evidence: Geological Society of London, Special Publication 247, pp. 159-182.

Channell, J.E.T., Curtis, J.H., and Flower, B.P., 2004. The Matuyama-Brunhes boundary interval (500-900 ka) in North Atlantic drift sediments: Geophysical Journal International, 158, pp. 489-505.

Ciaranfi, N., and D'Alessandro, A., 2005. Overview of the Montalbano Jonico area and section: a proposal for a boundary stratotype for the lower-middle Pleistocene, Southern Italy Foredeep: Quaternary International, 131, pp. 5-10.

Cita, M.B., Capraro, L., Ciaranfi, N., Di Stefano, E., Marino, M., Rio, D., Sprovieri, R., and Vai, G.B., 2006. Calabrian and Ionian: A proposal for the definition of Mediterranean stages for the Lower and Middle Pleistocene: Episodes, 29, pp. 107-114.

Clark, P.U., Archer, D., Pollard, D., Blum, J.D., Riale, J.A., Brovkin, V., Mix, A.C., Pisias, N.G., and Roy, M., 2006. The middle Pleistocene transition: characteristics, mechanisms, and implications for long-term changes in atmospheric $\mathrm{pCO}_{2}$ : Quaternary Science Reviews, 25, pp. 3150-3184.

Ding, Z.L., Derbyshire, E., Yang, S.L., Sun, J.M., and Liu, T.S., 2005. Stepwise expansion of desert environment across northern China in the past 3.5 Ma and implications for monsoon evolution: Earth and Planetary Science Letters, 237, pp. 45-55.

Dodonov, A.E., 2005. The stratigraphic transition and suggested boundary between the Early and Middle Pleistocene in the loess record of northern Eurasia. In: M.J. Head and P.L. Gibbard (Editors), Early-Middle Pleistocene transitions: the land-ocean evidence: Geological Society of London, Special Publication 247, pp. 209-219.

Gradstein, F.M., Ogg, J.G., and Smith, A.G., 2005. A geologic time scale 2004: Cambridge University Press, Cambridge, 589 pp. [Imprinted 2004].

Head, M.J., and Gibbard, P.L., 2005. Early-Middle Pleistocene transitions: an overview and recommendation for the defining boundary. In: M.J. Head and P.L. Gibbard (Editors), Early-Middle Pleistocene transitions: the land-ocean evidence: Geological Society of London, Special Publication 247 , pp. $1-18$.

Lisiecki, L.E., and Raymo, M.E., 2005. A Pliocene-Pleistocene stack of 57 globally distributed benthic $\delta^{18} \mathrm{O}$ records: Paleoceanography, 20, PA1003, doi:10.1029/2004PA001071.

Maslin, M.A., and Ridgwell, A.J., 2005. Mid-Pleistocene revolution and the 'eccentricity myth'. In: M.J. Head and P.L. Gibbard (Editors), Early-Middle Pleistocene transitions: the land-ocean evidence: Geological Society of London, Special Publication 247, pp. 19-34.

Pickering, K.T., Souter, C., Oba, T., Taira, A., Schaff, M., and Platzman, E., 1999. Glacio-eustatic control on deep-marine clastic forearc sedimentation, Pliocene-mid Pleistocene (c. 1180-600 ka) Kazusa Group, Japan: Journal of the Geological Society, London, 156, pp. 125-136.

Pillans, B., 2003. Subdividing the Pleistocene using the Matuyama-Brunhes boundary (MBB): an Australasian perspective: Quaternary Science Reviews, 22, pp. 1569-1577.

Richmond, G.M., 1996. The INQUA-approved provisional Lower-Middle Pleistocene boundary. In: C. Turner (Editor), The early Middle Pleistocene in Europe. Balkema, Rotterdam, pp. 319-327.

Sun, Y., Clemens, S.C., An, Z., and Yu, Z., 2006. Astronomical timescale and paleoclimatic implications of stacked 3.6-Myr monsoon records from the Chinese Loess Plateau: Quaternary Science Reviews, 25, pp. 33-48.
Torrence, C., and Compo, G.P., 1998. A practical guide to wavelet analysis: Bulletin of the American Meteorological Society, 79, pp. 61-78.

Tzedakis, P.C., Hooghiemstra, H., and Pälike, H., 2006. The last 1.35 million years at Tenaghi Philippon: revised chronostratigraphy and long-term vegetation trends: Quaternary Science Reviews, 25, pp. 3416-3430.

Zhou, L.P., and Shackleton, N.J., 1999. Misleading positions of geomagnetic reversal boundaries in Eurasian loess and implications for correlation between continental and marine sedimentary sequences: Earth and Planetary Science Letters, 168, pp. 117-130.

Martin J. Head is Professor and Chair-Elect of the Department of Earth Sciences at Brock University. He was previously at the University of Cambridge, and before that spent 14 years at the University of Toronto where he maintains a cross-appointment. He is a member of the ICS Subcommission on Quaternary Stratigraphy, and of its Working Group on the Lower-Middle Pleistocene Boundary. He is also a member of the INQUA Stratigraphy \& Chronology Commission. His interests include Cenozoic stratigraphy and marine palynology. Martin holds a PhD from the University of Aberdeen.

Brad Pillans is a Professorial Fellow in the Research School of Earth Sciences at The Australian National University where he runs a paleomagnetic laboratory. From 1983 to 1993 he was lecturer in Geology at Victoria University of Wellington, New Zealand. He is President of the INQUA Stratigraphy \& Chronology Commission and Chair of the ICS Working Group on the Lower-Middle Pleistocene Boundary. His research interests include geomorphology, Quaternary stratigraphy and dating methods.

Sarah A. Farquhar is a graduate of the University of Cambridge, and a member of Emmanuel College. She is currently a doctoral student in the Quaternary Palaeoenviroments Group at the Department of Geography, University of Cambridge, where she is examining the Pliocene dinoflagellate cyst record of the famous Rossello Composite Section in Sicily.
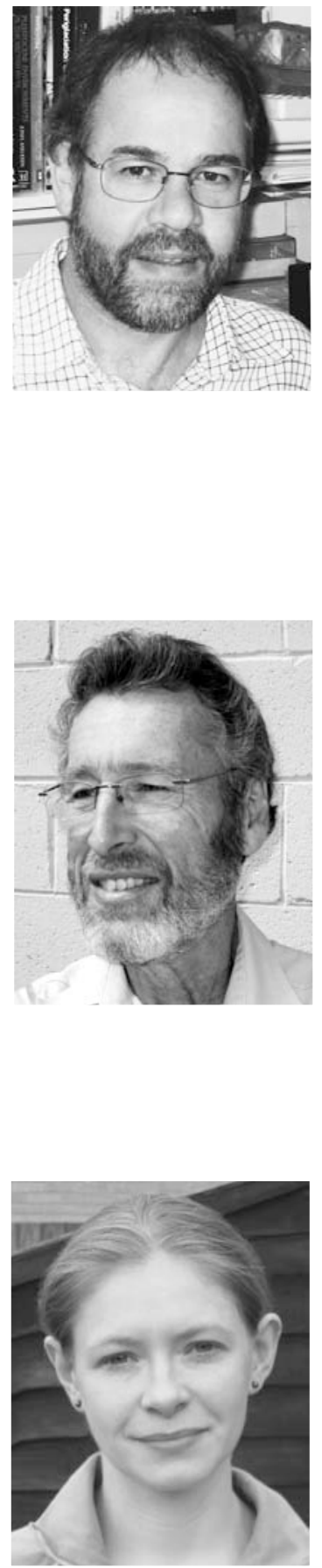